\title{
Das subalternidades aos sentidos da comunicação local
}

DOI: 10.1590/1809-58442018113

\section{Ingrid Gomes}

(Universidade Metodista de São Paulo, Escola de Comunicação, Educação e Humanidades, Programa de Pós-Graduação em Comunicação Social. São Bernardo do Campo, SP - Brasil)

https://orcid.org/0000-0002-6501-3721

\section{GONZÁLEZ, JorgeA. Sociologia das culturas subalternas.} Tradução de Osvandro J. de Moraes, Paulo B. C. Schettino e Rodrigo Gabrioti. Curitiba, Appris, 2016. 183p.

O pesquisador mexicano em Comunicação e Cultura, Jorge González, traz na obra "Sociologia das culturas subalternas” o entrelaçamento da cultura popular camponesa com as interfaces da comunicação, hegemonia, crenças e localidade. O investigador contemporâneo da temática de cibercultur@em comunidades emergentes reconhece nesse estudo o caminho cultural na região campesina da serra Atlacáyotl, no México dos anos 1980, como proposta ativa da comunicação e desenvolvimento local em trânsito.

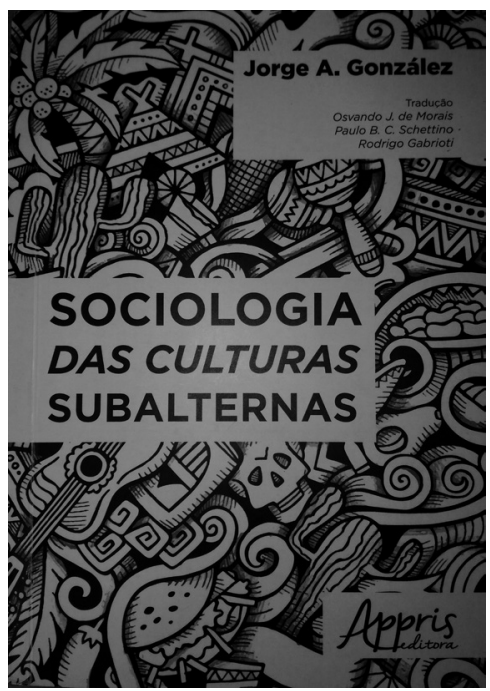

Logo no início da obra, González tem o cuidado em aproximar os contextos da região da serra, como seu objeto de análise, da cotidianidade dos locais esquecidos pelos poderes públicos e marcadamente pobres em recursos de sustento e subsistência na América Latina.

Depois, divide o texto em duas partes centrais: a primeira ocupa de conceituar sociologicamente os pressupostos históricos, abordagem filosófica e constructos culturais de referência; a segunda parte abarca o objeto de estudo da região da serra, suas crenças, relações sociais e estruturas orgânicas.

Adepto da teoria da cultura, a qual consiste na sistematização dos modos de produção e das suas relações na sociedade, incluindo a forma em que os sujeitos internalizam suas estruturas, as expõem e a atualizam, González recorre a dois autores principais para essa identidade de teoria da cultura, com Pierre Bourdieu em habitus e Antonio Gramsci em hegemonia (GONZÁLEZ, 2016, p.44).

São essenciais as duas recuperações teóricas para a análise cultural proposta na obra. Por habitus se abarca as percepções simbólicas e suas estruturas e modos de produção, desenvolvendo-se em determinado contexto com regras e funcionalidade prática. E o habitus na intersecção com a hegemonia. Habitus de classe é definido como a interiorização 
de elementos sociais e culturais pelo sujeito de acordo com as condições orgânicas da sua conjuntura cotidiana, desdobrando-se em ações comuns entre os vários indivíduos da mesma classe social (GONZÁLEZ, 2016, p.45-46).

Contudo, para além da sociologia da cultura, González baseia-se também na antropologia cultural, realizando diários de campos e vivência com os moradores da região da serra. Ressignifica o estudo a partir de metodologias de história oral, etnografia e inferências analíticas.

Na investigação propriamente do objeto, González salienta sobre a lógica capitalista nesses locais, na representação de Atlacáyotl, estar na inviabilidade do camponês reter qualquer excedente de sua produção, pois a rotina camponesa de produção agrícola (milho, vagem, pimenta chilli, entre outros) e a tentativa de gerar rendimento econômico por meio de criações de animais fundamentam-se no trabalho familiar e, por vezes, de troca de trabalho com outros moradores locais. Além dos outros fatores problemáticos, das terras desses camponeses serem majoritariamente impróprias tanto para a agricultura como para os pastos dos animais, a questão de ficarem à deriva dos fenômenos meteorológicos e do descaso dos representantes políticos da região (GONZÁLEZ, 2016, p.97).

Dos sistemas de crenças dos moradores de Atlacáyotl, González destaca as bruxas, o nagual, o duende, os mortos e os santinhos. Os quatro primeiros ocupam a função de zombamento, perigo, ameaça e opressão ao camponês. Os santinhos são representados como seres que ora podem servir de milagrosos e, em outro momento, podem desempenhar a categoria de castigadores. As bruxas e o nagual são identificados respectivamente como mulher indígena e animal indígena, já os duendes são singularizados como crianças ricas e brancas (GONZÁLEZ, 2016, p.144).

González associa esse sistema de crenças de caráter defensivo ao opressor como um habitus "defensivo/resistente" do camponês às influências de precariedade para sua subsistência, no sentido contínuo de "alerta defensivo".

As três festas principais: Carnaval, Todos os Santos e do Santo Padroeiro mantêm relações íntimas com o cotidiano cultural da região e são analisadas à luz do cruzamento com o sistema de crenças.

González indica as transformações nas relações sociais com a aproximação cultural do veículo do rádio na região das serras, também problematiza "as festas espetáculos”, no caso o do Santo Padroeiro, organizadas por moradores ricos e pela participação de visitantes da região urbana do México, além da própria migração e emigração dos indivíduos jovens na busca por melhores empregos e aponta a industrialização do transporte local modificando a paisagem, o habitus e a cotidianidade nas relações.

Esse olhar filosófico direcionado às políticas culturais em um determinado espaço comunitário amplia os resultados do conhecimento para pesquisas necessárias e inquietantes lá no México e por aqui. 
O autor explica seu ponto de vista para o caminho teórico, histórico e conjuntural selecionado, com a atenção de um etnógrafo expondo uma cultura subalternizada e de um comunicólogo preciso na ciência das relações cotidianas. Obra híbrida e ativa.

\section{Referências}

GONZÁLEZ, Jorge A. Sociologia das culturas subalternas. Tradução de Osvandro J. de Moraes, Paulo B. C. Schettino e Rodrigo Gabrioti. Curitiba, Appris, 2016. 183p.

\section{Ingrid Gomes}

Jornalista, especialista em Globalização e Cultura pela Fundação Escola de Sociologia e Política de São Paulo, mestre e doutora pela Universidade Metodista de São Paulo (Umesp) e pós-doutora em Processos Comunicacionais pela Umesp. Membro do Núcleo de Estudos de Comunicação Comunitária e Local (COMUNI). E-mail: ingridgomessp@yahoo.com.br.

Recebido em: 29.03.2017 Aceito em: 15.12.2017 